\title{
Haliea rubra sp. nov., a member of the Gammaproteobacteria from the Mediterranean Sea
}

\author{
Correspondence \\ Philippe Lebaron \\ lebaron@obs-banyuls.fr
}

\author{
Laurent Urios, ${ }^{1,2}$ Laurent Intertaglia, ${ }^{1,2}$ Françoise Lesongeur $^{3}$ \\ and Philippe Lebaron ${ }^{1,2}$ \\ ${ }^{1}$ UPMC Univ Paris 06, UMR 7621, Laboratoire d'Océanographie Biologique de Banyuls, \\ Observatoire Océanologique, F-66651, Banyuls/mer, France \\ ${ }^{2}$ CNRS, UMR 7621, LOBB, Observatoire Océanologique, F-66651, Banyuls/mer, France \\ ${ }^{3}$ Laboratoire de Microbiologie des Environnements Extrêmes, UMR 6197, IFREMER, Centre de \\ Brest, BP 70, 29280 Plouzané, France
}

\begin{abstract}
A novel aerobic, Gram-negative bacterium, designated strain CM41_15a ${ }^{\top}$, was isolated from the surface of coastal waters of the north-western Mediterranean Sea. Cells were non-motile straight rods that formed red colonies on marine agar medium. The $\mathrm{G}+\mathrm{C}$ content of the genomic DNA was $65 \mathrm{~mol} \%$. Phylogenetic analysis of the $16 \mathrm{~S}$ rRNA gene sequence placed the strain in the genus Haliea within the class Gammaproteobacteria. On the basis of the 16S rRNA gene sequence comparison and physiological and biochemical characteristics, strain CM41_15a ${ }^{\top}$ represents a novel species, for which the name Haliea rubra sp. nov. is proposed. The type strain is CM41_15a ${ }^{\top}\left(=\mathrm{DSM} 19751^{\top}=\mathrm{CIP} 109758^{\top}=\right.$ MOLA $\left.104^{\top}\right)$.
\end{abstract}

Members of the genus Microbulbifer, proposed originally by González et al. (1997), have been isolated from various marine environments, including salt marshes, intertidal sediments and coastal waters. Major amounts of iso-15:0 and iso-17: $1 \omega 9 c$ as well as ubiquinone Q-8 were defined as chemical markers for this genus (Yoon et al., 2004). Two strains isolated from the north-western Mediterranean Sea were studied. On the basis of their 16S rRNA gene sequences, the strains were phylogenetically related to the genus Microbulbifer. Fatty acid analysis revealed that iso$15: 0$ and iso-17: $1 \omega 9 c$ were either not present or present at very low levels in both strains. These differences, in addition to $16 \mathrm{~S}$ rRNA gene dissimilarities and other phenotypic characteristics, led to the proposal of two novel species of two new genera, Haliea salexigens DSM $19537^{\mathrm{T}}$ (Urios et al., 2008a) and Melitea salexigens DSM $19753^{\mathrm{T}}$ (Urios et al., 2008b). Recently, another strain was isolated from seawater collected from the same area from which $H$. salexigens and Melitea salexigens had been isolated. The $16 \mathrm{~S}$ rRNA gene sequence of the strain had a similarity of $94 \%$ with $H$. salexigens, its nearest relative. In this paper, we have characterized this isolate and show that it possesses characteristics that allow the proposition of a novel species of the genus Haliea.

The GenBank/EMBL/DDBJ accession number for the $16 \mathrm{~S}$ rRNA gene sequence of strain CM41_15a' is EU161717.

Graphs showing the effects of temperature, $\mathrm{pH}$ and salinity on the growth of strain $\mathrm{CM} 41{ }_{-} 15 \mathrm{a}^{\top}$ are available as supplementary material with the online version of this paper.
Seawater samples from a depth of $3 \mathrm{~m}$ were collected in February 2004 from the bay of Banyuls-sur-Mer $\left(42^{\circ} 29^{\prime} \mathrm{N}\right.$ $\left.3^{\circ} 08^{\prime} \mathrm{E}\right)$. Subsamples were spread on marine agar 2216 plates (MA; Difco) and incubated at $25{ }^{\circ} \mathrm{C}$ for 2 weeks. Colonies were picked and purified after three subcultures. Among these colonies, an isolate that formed red-coloured colonies was obtained and designated strain CM41_15 $\mathrm{a}^{\mathrm{T}}$.

Microscopic observations (AX70; Olympus) showed that cells of strain CM41_15 $\mathrm{a}^{\mathrm{T}}$ were non-motile rods, approximately $2.7 \pm 0.12 \mu \mathrm{m}$ long and $0.5 \pm 0.05 \mu \mathrm{m}$ wide. Cells were negatively stained for transmission electron microscopy (Raguénès et al., 1997). The Ryu $\mathrm{KOH}$ reaction (Powers, 1995) led to immediate cell lysis that was confirmed by microscopy (AX70; Olympus). This positive reaction indicated that the strain was Gram-negative.

Strain CM41_15a ${ }^{\mathrm{T}}$ was grown in marine broth 2216 (MB; Difco). To determine the range of salinities tolerated by the isolate, $\mathrm{MB}$ was prepared according to the composition provided by the manufacturer with the appropriate $\mathrm{NaCl}$ concentration. To determine the $\mathrm{pH}$ range, MES, PIPES, AMPSO or MOPS (Sigma) was added to MB to achieve the appropriate $\mathrm{pH}$. Cultures were incubated at $30{ }^{\circ} \mathrm{C}$ under aerobic conditions. The methods used for the determination of growth parameters were as reported by Wery et al. (2001b). Growth was observed at $15-44{ }^{\circ} \mathrm{C}$ with optimum growth at $30{ }^{\circ} \mathrm{C}$ (see Supplementary Fig. S1, available in IJSEM Online). Strain CM41_15a ${ }^{\mathrm{T}}$ grew at $\mathrm{NaCl}$ concentrations ranging from 7 to $42 \mathrm{~g} \mathrm{l}^{-1}$ and an optimum concentration could be defined as $35 \mathrm{~g} \mathrm{l}^{-1}$ (Supplementary Fig. S1). Growth occurred at pH 5.0-9.0, with an optimum 
at $\mathrm{pH} 8.0$ (Supplementary Fig. S1). To investigate the possibility of growth under anaerobic conditions, cultures were placed in an anaerobic jar on MA plates at optimal conditions of temperature, $\mathrm{pH}$ and salinity (Supplementary Fig. S1). No growth was observed after 10 days and thus the strain should be considered as being strictly aerobic.

Table 1. Characteristics that differentiate strain $C M 41 \_15 a^{\top}$ from related species

Strains: 1, Microbulbifer maritimus JCM $12187^{\mathrm{T}}$ (data from Yoon et al., 2004); 2, Microbulbifer hydrolyticus DSM 11525 ${ }^{\mathrm{T}}$ (González et al., 1997); 3 , Microbulbifer salipaludis KCCM 41586 ${ }^{\mathrm{T}}$ (Yoon et al., 2003a); 4, Microbulbifer elongatus DSM 6810 ${ }^{\mathrm{T}}$ (Yoon et al. 2003b); 5, Melitea salexigens DSM $19753^{\mathrm{T}}$ (Urios et al., 2008b); 6, strain CM41_15a ${ }^{\mathrm{T}}$ (Haliea rubra sp. nov.); 7, H. salexigens DSM $19537^{\mathrm{T}}$ (Urios et al., 2008a). All strains have a ubiquinone (Q-8) system. +, Positive; -, negative; (+), weakly positive; ND, no data available.

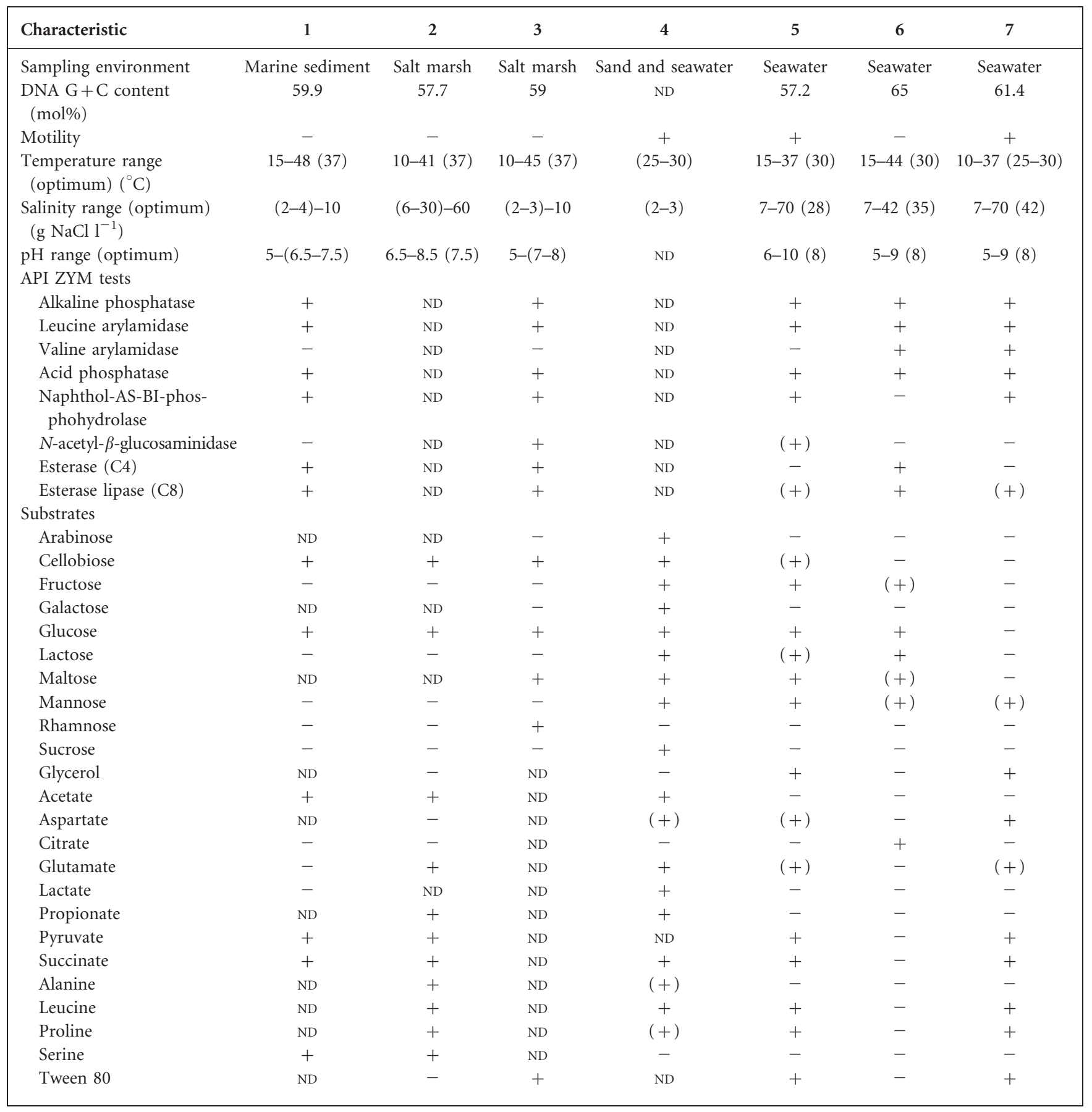


The ability of strain CM41_15a ${ }^{\mathrm{T}}$ to use various substrates was investigated using Biolog GN2 MicroPlates (Tang et al., 1998), according to the manufacturer's instructions. Positive reactions were obtained for Tween 40, D-glucose, D-lactose, citrate and $\gamma$-hydroxybutyric acid. Weakly positive reactions were obtained for i-erythritol, D-fructose, maltose, D-mannose and L-pyroglutamate. A comparison between strain CM41_15 $\mathrm{a}^{\mathrm{T}}$ and its closest relatives is presented in Table 1.

Enzymic activities were investigated using the API ZYM system (bioMerieux) according to the manufacturer's instructions. Positive reactions were obtained for alkaline phosphatase, esterase (C4), esterase lipase (C8), leucine arylamidase, valine arylamidase and acid phosphatase (Table 1).
Analysis of the fatty acid methyl esters of strain CM41_15 $\mathrm{a}^{\mathrm{T}}$ grown in $\mathrm{MB}$ was performed by the Identification Service of the Deutsche Sammlung von Mikroorganismen und Zellkulturen (DSMZ; Braunschweig, Germany). The fatty acid composition for strain CM41_15a ${ }^{\mathrm{T}}$ was as follows: $18: 1 \omega 7 c(40.2 \%), 16: 1 \omega 7 c /$ iso-15 $2-\mathrm{OH}(30.5 \%), 16: 0(13.0 \%), 12: 13-\mathrm{OH}(3.5 \%)$, $17: 1 \omega 8 c(2.0 \%), 15: 0(1.2 \%), 17: 1 \omega 6 c(1.1 \%), 12: 02-$ $\mathrm{OH}(1.1 \%), 17: 0(1.0 \%), 14: 0(0.7 \%), 18: 0(0.7 \%)$ and $15: 1 \omega 6 c(0.3 \%)$ (Table 2). Iso- $15: 0$ and iso- $17: 1 \omega 9 c$, two major fatty acids found in all Microbulbifer strains, were not detected in strain CM41_15a ${ }^{\mathrm{T}}$. The two major fatty acids of strain CM41_15a ${ }^{\mathrm{T}}, 18: 1 \omega 7 c$ and $16: 1 \omega 7 c /$ iso- 15 2-OH, were also major fatty acids of $H$. salexigens DSM $19537^{\mathrm{T}}$. The two major fatty acids of Melitea salexigens

Table 2. Cellular fatty acid compositions (\%) of strain $\mathrm{CM} 41{ }_{-} 15 \mathrm{a}^{\top}$ and related species

Strains: 1, Microbulbifer maritimus JCM $12187^{\mathrm{T}}$ (data from Yoon et al., 2004); 2, Microbulbifer hydrolyticus DSM $11525^{\mathrm{T}}$ (González et al., 1997); 3, Microbulbifer salipaludis KCCM 41586 ${ }^{\mathrm{T}}$ (Yoon et al., 2003a); 4, Microbulbifer elongatus DSM $6810^{\mathrm{T}}$ (Yoon et al., 2003b); 5, Melitea salexigens DSM $19753^{\mathrm{T}}$ (Urios et al., 2008b); 6, strain CM41_15a ${ }^{\mathrm{T}}$ (Haliea rubra sp. nov.); 7, H. salexigens DSM $19537^{\mathrm{T}}$ (Urios et al., 2008a). -, Not detected.

\begin{tabular}{|c|c|c|c|c|c|c|c|}
\hline Fatty acid & 1 & 2 & 3 & 4 & 5 & 6 & 7 \\
\hline $10: 0$ & 1.3 & 1.7 & 2.4 & 1.6 & - & - & - \\
\hline $11: 0$ & - & - & - & - & 0.7 & - & 1.0 \\
\hline $12: 0$ & - & - & - & - & 0.3 & - & 1.6 \\
\hline $13: 0$ & - & - & - & - & 0.4 & - & 1.3 \\
\hline $14: 0$ & 1.0 & 1.2 & 2.6 & 0.7 & 0.8 & 0.7 & 1.3 \\
\hline $15: 0$ & 1.6 & 1.5 & 1.7 & 0.9 & 5.3 & 1.2 & 4.5 \\
\hline $16: 0$ & 8.7 & 11.4 & 16.3 & 7.1 & 3.9 & 13.0 & 2.0 \\
\hline $17: 0$ & 1.3 & 2.9 & 2.2 & 2.5 & 13.0 & 1.0 & 9.3 \\
\hline $18: 0$ & - & 1.6 & 1.4 & 1.2 & 0.5 & 0.7 & - \\
\hline $17: 0$ cyclo & 2.3 & 5.7 & - & - & - & - & - \\
\hline $19: 0 \omega 8 c$ & 1.4 & 1.0 & - & - & - & - & - \\
\hline iso-11:0 & 10.0 & 5.7 & 4.8 & 6.5 & - & - & - \\
\hline iso- $13: 0$ & - & - & - & - & 1.0 & - & - \\
\hline iso- $15: 0$ & 25.9 & 24.4 & 19.4 & 20.7 & 2.0 & - & - \\
\hline iso- $15: 1$ & 0.8 & 1.0 & 0.7 & 1.0 & - & - & - \\
\hline iso- $16: 0$ & - & - & - & 0.5 & - & - & - \\
\hline iso- $17: 0$ & 6.9 & 10.4 & 5.5 & 9.9 & 1.3 & - & - \\
\hline anteiso-17:0 & - & - & - & 0.8 & - & - & - \\
\hline iso- $17: 1 \omega 9 c$ & 12.6 & 10.1 & 9.5 & 11.3 & - & - & - \\
\hline $15: 1 \omega 6 c$ & - & - & - & - & - & 0.3 & 5.8 \\
\hline $17: 1 \omega 6 c$ & - & - & - & - & 0.6 & 1.1 & 2.7 \\
\hline $17: 1 \omega 8 c$ & - & 0.5 & 1.0 & 1.8 & 34.1 & 2.0 & 23.9 \\
\hline $18: 1 \omega 5 c$ & - & - & 0.7 & - & - & - & - \\
\hline $18: 1 \omega 7 c$ & 5.6 & 8.9 & 11.8 & 16.3 & 11.4 & 40.2 & 17.5 \\
\hline $10: 03-\mathrm{OH}$ & 1.7 & 1.0 & 1.2 & 1.6 & 1.7 & - & 1.8 \\
\hline $11: 03-\mathrm{OH}$ & - & - & - & - & 4.6 & - & 3.3 \\
\hline $12: 02-\mathrm{OH}$ & - & - & - & - & - & 1.1 & - \\
\hline $12: 03-\mathrm{OH}$ & - & - & - & - & - & - & 1.1 \\
\hline $12: 13-\mathrm{OH}$ & - & - & - & - & 0.5 & 3.5 & - \\
\hline $16: 02-\mathrm{OH}$ & - & - & 0.9 & - & - & - & - \\
\hline iso-11:0 $3-\mathrm{OH}$ & 14.2 & 6.2 & 5.7 & 7.7 & 4.3 & - & 3.3 \\
\hline iso-17:0 $3-\mathrm{OH}$ & - & - & 0.9 & - & - & - & - \\
\hline $16: 1 \omega 7 c /$ iso- $152-\mathrm{OH}$ & 2.2 & 2.7 & 7.1 & 6.0 & 9.0 & 30.5 & 21.2 \\
\hline
\end{tabular}


DSM $19753^{\mathrm{T}}(17: 0$ and $17: 1 \omega 8 c)$ were present in minor amounts in strain CM41_15 $\mathrm{a}^{\mathrm{T}}$. As observed for Microbulbifer species, fatty acids $11: 0,12: 0,13: 0,11: 0$ $3-\mathrm{OH}$ and 12:0 3-OH were not detected in strain CM41_15 $\mathrm{a}^{\mathrm{T}}$. In contrast, fatty acids $10: 0$, iso- $11: 0$, iso$15: 1$, iso-17:0 and iso-15:0, which are always present in Microbulbifer species, but are not found in $H$. salexigens DSM $19537^{\mathrm{T}}$, were not found in strain CM41_15a $\mathrm{a}^{\mathrm{T}}$. Fatty acids $17: 1 \omega 6 c$ and $15: 1 \omega 6 c$ were found in $H$. salexigens DSM $19537^{\mathrm{T}}$ and strain CM41_15a $\mathrm{a}^{\mathrm{T}}$, but not in any Microbulbifer strains studied.

Analysis of respiratory quinones and polar lipids were carried out by the Identification Service of the DSMZ and Dr Brian Tindall (DSMZ). Strain CM41_15a ${ }^{\mathrm{T}}$ had a ubiquinone (Q-8) system.

Genomic DNA was extracted as described by Wery et al. (2001a). The DNA G+C content was determined by means of thermal denaturation, using the method of Marmur \& Doty (1962) and the conditions described by Raguénès et al. (1997). The $\mathrm{G}+\mathrm{C}$ content of the genomic DNA of strain CM41_15a $\mathrm{a}^{\mathrm{T}}$ was $64.8 \pm 0.9 \mathrm{~mol} \%$ (SEM; 3 determinations). The $16 \mathrm{~S}$ rRNA gene was amplified and sequenced as described by Agogué et al. (2005). The sequence was analysed as described by Urios et al. (2006). Strain CM41_15a $\mathrm{a}^{\mathrm{T}}$ was shown to be phylogenetically affiliated to the genus Haliea in the class Gammaproteobacteria (Fig. 1). The closest relative was $H$. salexigens DSM $19537^{\mathrm{T}}$, with a sequence similarity of $94 \%$.

Strain CM41_15 $\mathrm{a}^{\mathrm{T}}$ could be distinquished from its nearest phylogenetically related strains based on differences in several phenotypic properties, as shown in Tables 1 and 2. Based on these differences, we propose that strain CM41_15a $\mathrm{a}^{\mathrm{T}}$ represents a novel species of the genus Haliea. Because of the red-coloured colonies of strain CM41_15a $\mathrm{a}^{\mathrm{T}}$, the name Haliea rubra sp. nov. is proposed.

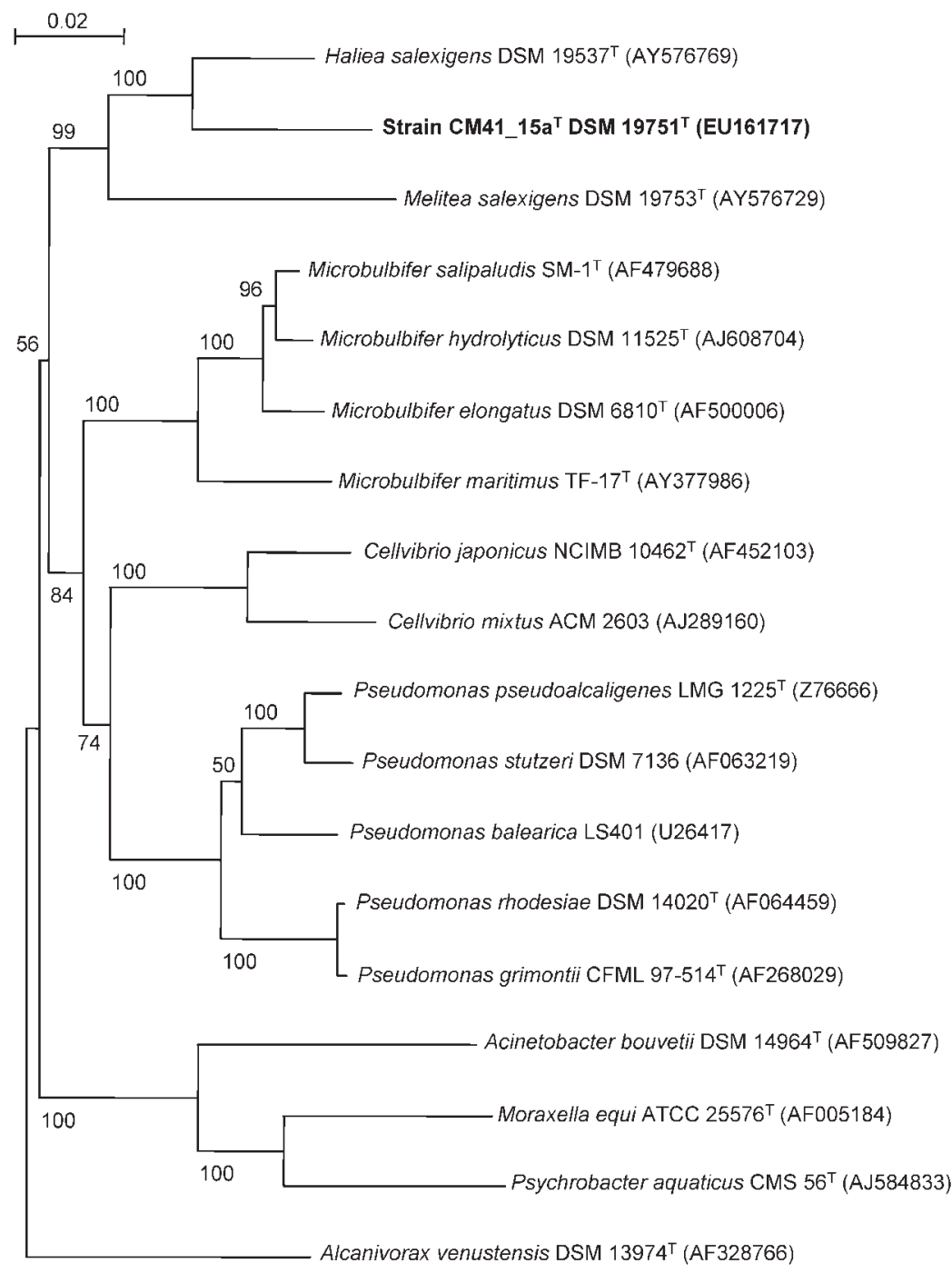

http://ijs.sgmjournals.org
Fig. 1. Phylogenetic tree, based on $16 \mathrm{~S}$ rRNA gene sequences, showing the position of strain CM41_15a'. The tree corresponds to an unrooted tree obtained using the neighbour-joining algorithm (with Kimura corrections). Bootstrap percentages (based on 1000 replications) are shown at branch points. Bar, 0.02 substitutions per nucleotide position. 


\section{Description of Haliea rubra sp. nov.}

Haliea rubra (ru'bra. L. fem. adj. rubra red).

Forms red colonies on MA. Cells are Gram-negative, nonmotile rods, $2.7 \pm 0.12 \mu \mathrm{m}$ long and $0.5 \pm 0.05 \mu \mathrm{m}$ wide. Growth occurs at $15-44{ }^{\circ} \mathrm{C}$ (optimum, $30^{\circ} \mathrm{C}$ ), at pH 5.0 9.0 (optimum, 8.0) and at salinities in the range $7-42 \mathrm{~g}$ $\mathrm{NaCl} 1^{-1}$ (optimum, $35 \mathrm{~g} \mathrm{l}^{-1}$ ). Positive reactions with Biolog GN2 plates are obtained for Tween 40, D-glucose, Dlactose, citrate and $\gamma$-hydroxybutyric acid. Positive API ZYM reactions for enzyme activities are obtained for alkaline phosphatase, esterase (C4), esterase lipase (C8), leucine arylamidase, valine arylamidase and acid phosphatase. Oxidase- and catalase-positive. Major fatty acids are $18: 1 \omega 7 \mathrm{c}, 16: 1 \omega 7 c /$ iso- 15 2-OH and 16:0. The DNA $\mathrm{G}+\mathrm{C}$ content of the type strain is $65 \mathrm{~mol} \%$.

The type strain, CM41_15a $\mathrm{a}^{\mathrm{T}} \quad\left(=\mathrm{DSM} \quad 19751^{\mathrm{T}}=\mathrm{CIP}\right.$ $109758^{\mathrm{T}}=$ MOLA $104^{\mathrm{T}}$ ), was isolated from surface seawater in the bay of Banyuls-sur-Mer $\left(42^{\circ} 29^{\prime} \mathrm{N} 3^{\circ} 08^{\prime} \mathrm{E}\right)$.

\section{Acknowledgements}

This work was supported by the Equipe Mixte de Recherche linking the Université Pierre et Marie Curie and the Centre National de la Recherche Scientifique to the Pierre Fabre Laboratories. The project was also partly funded by the EU project BASICS (EVK3-CT-200200018) and by a grant from the Institut Français de la Biodiversité (IFB-GICC, Paris, France). The project was also carried out in the frame of the MarBEF Network of Excellence 'Marine Biodiversity and Ecosystem Functioning' which is funded in the Community's Sixth Framework Programme (contract no. GOCECT-2003-505446). This publication is contribution number MPS-09021 of MarBEF.

\section{References}

Agogué, H., Casamayor, E. O., Bourrain, M., Obernosterer, I., Joux, F., Herndl, G. J. \& Lebaron, P. (2005). A survey on bacteria inhabiting the sea surface microlayer of coastal ecosystems. FEMS Microbiol Ecol 54, 269-280.

González, J. M., Mayer, F., Moran, M. A., Hodson, R. E. \& Whitman, W. B. (1997). Microbulbifer hydrolyticus gen. nov., sp. nov., and Marinobacterium georgiense gen. nov., sp. nov., two marine bacteria from a ligninrich pulp mill waste enrichment community. Int J Syst Bacteriol 47, 369-376.
Marmur, J. \& Doty, P. (1962). Determination of the base composition of deoxyribonucleic acid from its thermal denaturation temperature. $J$ Mol Biol 5, 109-118.

Powers, E. M. (1995). Efficacy of the Ryu nonstaining $\mathrm{KOH}$ technique for rapidly determining gram reactions of food-borne and waterborne bacteria and yeasts. Appl Environ Microbiol 61, 3756-3758.

Raguénès, G., Christen, R., Guézennec, J., Pignet, P. \& Barbier, G. (1997). Vibrio diabolicus sp. nov., a new polysaccharidic-secreting organism isolated from a deep-sea hydrothermal vent polychete annelid, Alvinella pompejana. Int J Syst Bacteriol 47, 989-995.

Tang, Y. W., Ellis, N. M., Hopkins, M. K., Smith, D. H., Dodge, D. E. \& Persing, D. H. (1998). Comparison of phenotypic and genotypic techniques for identification of unusual aerobic pathogenic gramnegative bacilli. J Clin Microbiol 36, 3674-3679.

Urios, L., Agogué, H., Lesongeur, F., Stackebrandt, E. \& Lebaron, P. (2006). Balneola vulgaris gen. nov., sp. nov., a member of the phylum Bacteroidetes from the north-western Mediterranean Sea. Int J Syst Evol Microbiol 56, 1883-1887.

Urios, L., Intertaglia, L., Lesongeur, F. \& Lebaron, P. (2008a). Haliea salexigens gen. nov., sp. nov., a member of the Gammaproteobacteria from the Mediterranean Sea. Int J Syst Evol Microbiol 58, 1233-1237.

Urios, L., Agogué, H., Intertaglia, L., Lesongeur, F. \& Lebaron, P. (2008b). Melitea salexigens gen. nov., sp. nov., a gammaproteobacterium from the Mediterranean Sea. Int J Syst Evol Microbiol 58, 2479 2483.

Wery, N., Lesongeur, F., Pignet, P., Derennes, V., Cambon-Bonavita, M., Godfroy, A. \& Barbier, G. (2001a). Marinitoga camini gen. nov., sp. nov., a rod-shaped bacterium belonging to the order Thermotogales, isolated from a deep-sea hydrothermal vent. Int J Syst Evol Microbiol 51, 495-504.

Wery, N., Moricet, J., Cueff, V., Jean, J., Pignet, P., Lesongeur, F., Cambon-Bonavita, M. \& Barbier, G. (2001b). Caloranaerobacter azorensis gen. nov., sp. nov., an anaerobic thermophilic bacterium isolated from a deep-sea hydrothermal vent. Int J Syst Evol Microbiol 51, 1789-1796.

Yoon, J.-H., Kim, I.-G., Shin, D.-Y., Kang, K. H. \& Park, Y.-H. (2003a). Microbulbifer salipaludis sp. nov., a moderate halophile isolated from a Korean salt marsh. Int J Syst Evol Microbiol 53, 53-57.

Yoon, J.-H., Kim, H., Kang, K. H., Oh, T.-K. \& Park, Y.-H. (2003b). Transfer of Pseudomonas elongata Humm 1946 to the genus Microbulbifer as Microbulbifer elongatus comb. nov. Int J Syst Evol Microbiol 53, 1357-1361.

Yoon, J.-H., Kim, I.-G., Oh, T.-K. \& Park, Y.-H. (2004). Microbulbifer maritimus sp. nov., isolated from an intertidal sediment from the Yellow Sea, Korea. Int J Syst Evol Microbiol 54, 1111-1116. 